\title{
ASEAN FRAMEWORK AGREEMENT ON INTELLECTUAL PROPERTY CO-OPERATION ${ }^{3}$
}

Bangkok, 15 December 1995

The Governments of . . ., Member States of the Association of South East Asian Nations (hereinafter refrerred to as 'ASEAN');

Recognising the important role of intellectual property rights in the conduct of trade and the flow of investment among the Member States of ASEAN and the importance of cooperation in intellectual property in the region;

Have agreed as follows:

\section{Article 1 : Objectives}

1. Member States shall strengthen their cooperation in the field of intellectual property through an open and outward looking attitude with a view to contributing to the promotion and growth of regional and global trade liberalisation.

2. Member States shall promote cooperation in the field of intellectual property among government agencies as well as among the private sectors and professional bodies of ASEAN.

3. Member States shall explore appropriate intra-ASEAN cooperation arrangements in the field of intellectual property, contributing to the enhancement of ASEAN solidarity as well as to the promotion of technological innovation and the transfer and dissemination of technology.

4. Member States shall explore the possibility of setting up and ASEAN patent system, including an ASEAN Patent Office, if feasible, to promote the region-wide protection of patents bearing in mind developments on regional and international protection of patents.

5. Member States shall explore the possibility of setting up of an ASEAN trademark system, including an ASEAN Trademark Office, if feasible, to promote the region-wide protection of trademarks bearing in mind developments on regional and international protection of trademarks.

6. Member States shall have consultations on the development of their intellectual property regimes with a view to creating ASEAN standards and practices which are consistent with international standards.

\section{Article 2 : Principles}

1. Member States shall abide by the principle of mutual benefits in the implementation of measures or initiatives aimed at enhancing ASEAN intellectual property cooperation.

2. Member States, being mindful of the international conventions on intellectual property rights to which they are parties, and the international obligations assumed under the provisions of the Agreement on Trade Related Aspects of Intellectual Property Rights, shall implement intra-ASEAN intellectual property arrangements in a manner in line with

\footnotetext{
${ }^{3}$ Text from op.cit.n.1 p.105.
} 
the objectives, principles, and norms set out in such relevant conventions and the Agreement on TRIPS.

3. Member States shall strive to implement intra-ASEAN intellectual property cooperation arrangements which are beneficial to creators, producers and users of intellectual property and in a manner conducive to social and economic welfare.

4. Member States shall recognise and respect the protection and enforcement of intellectual property rights in each Member State and the adoption of measures necessary for the protection of public health and nutrition and the promotion of the public interests in sectors of vital importance to the Member States socio-economic and technological development, which are consistent with their international obligations.

5. Member States are conscious of and understand the necessity for each Member State to adopt appropriate measures to prevent the abuse of intellectual property rights by right holders or the resort to practices which unreasonably restrain trade or adversely affect the international transfer of technology.

\section{Article 3 : Scope of Cooperation}

1. Cooperation shall include, inter alia, the fields of copyright and related rights, patents, trademarks, industrial designs, geographical indications, undisclosed information and layout designs of integrated circuits.

2. Cooperative activities under this Agreement shall aim, among others, to strengthen ASEAN intellectual property administration; to enhance ASEAN cooperation in intellectual property enforcement and protection; and to explore the possibility of setting up the ASEAN patent and trademark systems.

3. Cooperative activities under this Agreement shall include, inter alia:

3.1 Activities to enhance intellectual property enforcement and protection:

a. Effective protection and enforcement of intellectual property rights;

b. Cross border measures cooperation;

c. Networking of judicial authorities and intellectual property enforcement agencies.

3.2 Activities to strengthen ASEAN intellectual property administration such as:

a. automation to improve the administration of intellectual property; and

b. the creation of an ASEAN database on intellectual property registration.

3.3 Activities to strengthen intellectual property legislation such as:

a. comparative study of the procedures, practices and administration of ASEAN intellectual property offices; and

b. activities related to the implementation of the TRIPS Agreement and other recognised international intellectual property conventions. 
3.4 Activities to promote human resources development such as:

a. Networking of intellectual property training facilities or centres of excellence on intellectual property and to explore the possibility of establishing a regional training institute for intellectual property or other appropriate structures; and

b. Exchange of intellectual property personnel and experts.

3.5 Activities to promote public awareness of intellectual property rights.

3.6 Activities to promote private sector cooperation in intellectual property such as to explore the possibility of:

a. The establishment of an ASEAN Intellectual Property Association; and

b. Providing arbitration services or other alternative dispute resolution mechanisms for the resolution of intellectual property disputes.

3.7 Information exchange on intellectual property issues.

3.8 Other cooperative activities as determined by Member States.

4. Details and the modalities to implement the cooperative activities are to be formulated in the form of a program of action on intellectual property under this Framework Agreement.

\section{Article 4 : Review of Cooperative Activities}

An ASEAN mechanism shall be established, comprising representatives from Member States, to review the cooperative activities under this Agreement. It shall meet on a regular basis to review the progress of the cooperative activities and any arrangement arising therefrom and to submit its findings and recommendations to the ASEAN Senior Economic Officials Meeting (SEOM). The ASEAN Secretariat shall give necessary secretariat support to the mechanism.

\section{Article 5 : Consultations}

1. Any differences between the Member States concerning the interpretation or application of this Agreement shall, as far as possible, be settled amicably between the parties.

2. Member States shall accord adequate opportunity for consultations regarding any representations made by other Member States in relation to the differences between them. If such differences cannot be settled amicably, they shall be dealt with by the SEOM and finally by the ASEAN Economic Ministers Meeting.

\section{Article 6 : General Provisions}

Nothing in this Agreement shall prejudice any existing or future bilateral or multilateral agreement entered into by any Member State or the national laws of each Member State relating to the protection and enforcement of intellectual property rights.

\section{Article 7 : Funding}

Activities under this Agreement will be subject to the availability of funds. Expenses incurred as a result of any activity undertaken by a Member State to fulfil the objectives of this Agreement shall be borne by the Member State concerned unless all Member States decide otherwise. 


\section{Article 8 : Final Provisions}

1. The respective Governments of Member States shall undertake the appropriate measures to fulfil the agreed obligations arising from this Agreement.

2. Any amendment to this Agreement shall be made by consensus and shall become effective upon acceptance by all Member States.

3. No reservation shall be made with respect to any of the provisions of this Agreement.

4. This Agreement shall be deposited with the Secretary-General of ASEAN who shall promptly furnish a certified copy thereof to each Member State.

5. This Agreement shall enter into force upon the deposit of instruments of ratification or acceptance by all signatory governments with the Secretary-General of ASEAN.

.. .

\section{ASEAN FRAMEWORK AGREEMENT ON SERVICES ${ }^{4}$}

Bangkok, 15 December 1995

The Governments of ..., Member States of the Association of South East Asian Nations (hereinafter referred to as 'ASEAN');

Reiterating their commitments to the rules and principles of the General Agreement on Trade in Services (hereinafter referred to as 'GATS') and noting that Article V of GATS permits the liberalising of trade in services between or among the parties to an economic integration agreement;

Affirming that ASEAN Member States shall extend to one another preference in trade in services;

Have agreed as follows:

Article I : Objectives

The objectives of the Member States under the ASEAN Framework Agreement on Services (hereinafter referred to as 'this Framework Agreement') are:

(a) to enhance cooperation in services amongst Member States in order to improve the efficiency and competitiveness, diversify production capacity and supply and distribution of services of their service suppliers within and outside ASEAN;

\footnotetext{
${ }^{4}$ Text from op.cit.n.1 p.110.
} 